\title{
Pengaruh Electronic Word of Mouth, Kualitas Website, Reputasi Vendor dan Persepsi Kemudahan Transaksi terhadap Keputusan Pembelian Situs Online Bukalapak di Yogyakarta
}

\author{
Ikhsan Nurahman \\ Universitas Pembangunan Nasional "Veteran" Yogyakarta, Yogyakarta \\ Anggraeni Pratama Indrianto* \\ Universitas Pembangunan Nasional "Veteran" Yogyakarta, Yogyakarta
}

Email: anggraeniprtm@gmail.com

\begin{abstract}
Abstrak
Penelitian ini bertujuan untuk menganalisis pengaruh electronic word of mouth, kualitas website, reputasi vendor, dan persepsi kemudahan transaksi terhadap keputusan pembelian situs online Bukalapak. Teknik sampling yang digunakan adalah purposive sampling dengan kriteria pengguna situs jual beli online dengan jumlah 120 responden. Teknik analisis yang digunakan adalah analisis regresi linier berganda dan uji hipotesis menggunakan uji $\mathrm{F}$ secara bersama-sama (simultan) dan uji t secara parsial. Dari hasil analisis menunjukkan bahwa variabel electronic word of mouth, kualitas website, reputasi vendor, dan persepsi kemudahan transaksi secara bersama-sama berpengaruh dan signifikan terhadap keputusan pembelian situs online Bukalapak. Kemudian secara parsial, keempat variabel independen yang terdiri electronic word of mouth, kualitas website, reputasi vendor, dan persepsi kemudahan transaksi bernilai positif dan signifikan.
\end{abstract}

Kata kunci: Electronic Word of Mouth, Kualitas Website, Reputasi Vendor, Persepsi Kemudahan Transaksi, dan Keputusan Pembelian

\section{Pendahuluan}

Gaya hidup masyarakat yang selalu menginginkan kemudahan dan kepraktisan dalam hidupnya tentu sangat erat kaitannya dengan adanya internet. Hal tersebut dibuktikan dengan meningkatnya jumlah pengguna internet dari tahun ke tahun. Menurut data dari Kominfo, pada tahun 2005 pengguna internet mencapai 1 miliar, sedangkan pada tahun 2010 mencapai angka 2 miliar pengguna dan diperkirakan secara keseluruhan, jumlah pengguna internet di seluruh dunia diproyeksikan bakal mencapai 3 miliar orang pada 2015. Tiga tahun setelahnya, pada 2018, diperkirakan sebanyak 3.6 miliar manusia di bumi bakal mengakses internet setidaknya sekali tiap satu bulan Hidayat (2014). Kemudahan dan kepraktisan yang ditawarkan internet tidak hanya terbatas dalam pencarian informasi, namun juga telah merambah di dunia jual-beli yang bersifat online. Dengan banyaknya e-commerce dan online shop yang diciptakan, tentu akan mempermudah konsumen untuk mendapatkan produk yang mereka inginkan. Turban, King, Lee, \& Viehland (2004) menjelaskan bahwa dengan semakin banyaknya dan semakin mudahnya fasilitas internet, belanja online menjadi tren baru yang terasa lebih sederhana, efisien dan cepat tanpa ditemui hambatan bisnis yang berarti. Namun kemudahan-kemudahan dari sistem belanja online tersebut ternyata juga menimbulkan permasalahan baru, diantaranya sulitnya memilih website jual beli online yang memiliki kualitas yang baik. Oleh karena itu 


\section{Ikhsan Nurahman, Anggraeni Pratama Indrianto}

untuk memilih e-commerce yang tepat, konsumen biasanya melihat dari kualitas website, reputasi dari para vendor, seberapa mudah digunakan, apakah mampu memberikan informasi yang diinginkan dan melihat rating atau rekomendasi dari seseorang yang telah berbelanja sebelumnya (electronic word of mouth).

Salah satu e-commerce jual beli online yang concern mengenai hal-hal diatas ialah Bukalapak. Bukalapak merupakan perusahaan dalam bidang e-commerce yang sudah terkemuka di Indonesia yang menjadi sarana untuk jual beli dari konsumen ke konsumen sehingga semua orang dapat menjual barangnya melalui toko online miliknya sendiri. Namun seperti yang kita ketahui, Bukalapak bukanlah satu-satunya e-commerce yang ada di tengahtengah masyarakat Indonesia. Beberapa e-commerce yang memiliki kualitas dan kinerja yang relatif sama dapat memiliki kinerja yang berbeda-beda di pasar karena perbedaan persepsi yang tertancap di benak konsumen. Oleh karena itu suatu merek yang dirancang perusahaan harus dapat memenuhi apa yang dibutuhkan dan diinginkan konsumen serta harus dikomunikasikan dengan baik untuk dapat memenangkan persaingan. Untuk dapat memenangkan persaingan, Bukalapak harus bersaing dengan $e$-commerce yang lebih dahulu menguasai pasar dan $e$ commerce baru yang terus berupaya menciptakan inovasi. Beberapa e-commerce jual beli yang telah mendapatkan posisi strategis di benak masyarakat, antara lain: Shopee. Lazada, Tokopedia, dan sebagainya.

Menurut riset yang dilakukan oleh Indonesian Ecommerce Association (IdEA), persaingan e-commerce yang ada di Indonesia memang tidak dapat dihindarkan. Berbagai platform juga melakukan berbagai cara agar senantiasa menjadi pilihan utama pengguna. Berikut 10 e-commerce yang paling banyak dikunjungi masyarakat Indonesia menurut Indonesian Ecommerce Association:

Tabel 1. E-Commerce yang Paling Banyak di Kunjungi di Indonesia (2019)

\begin{tabular}{|c|c|c|}
\hline No. & Nama E-Commerce & Jumlah Pengunjung \\
\hline 1. & Tokopedia & 805,5 juta kunjungan \\
\hline 2. & Bukalapak & 588,3 juta kunjungan \\
\hline 3. & Shopee & 476,5 juta kunjungan \\
\hline 4. & Lazada & 476,5 juta kunjungan \\
\hline 5. & Blibli.com & 210,4 juta kunjungan \\
\hline 6. & Orami & 52,4 juta kunjungan \\
\hline 7. & JD.ID & 50,7 juta kunjungan \\
\hline 8. & Bhinneka & 32,8 juta kunjungan \\
\hline 9. & Sociolla & 28,6 juta kunjungan \\
\hline 10. & Amazone & 27,9 juta kunjungan \\
\hline
\end{tabular}

Sumber: (Idea, 2019)

Menghadapi ketatnya persaingan, nyatanya bukanlah satu-satunya permasalahan yang harus diselesaikan oleh Bukalapak. Ternyata Bukalapak juga memiliki permasalahan lain. Menurut hasil survey dari E-CommerceIQ menunjukkan bahwa banyak pengguna Bukalapak yang mengeluhkan tidak nyamannya pengalaman berbelanja di layanan e-commerce tersebut. Keluhan tidak nyamannya pengalaman belanja di Bukalapak terbilang lebih tinggi ketimbang lima e-commerce lain. Ketidaknyamanan penggunaan terhadap Bukalapak ini menempati posisi kedua dari hal yang tidak disukai pengguna ketika berbelanja di Bukalapak (15.8\%). Sementara keluhan ketidaknyamanan berbelanja di Blibli.com berada diperingkat tiga (10.6\%), JD.ID peringkat tiga (13.8\%), Lazada peringkat empat (11.3\%), Shopee peringkat empat 


\section{Ikhsan Nurahman, Anggraeni Pratama Indrianto}

(12.7\%), dan Tokopedia peringkat tiga (12.9\%). Ketidaknyamanan tersebut disebabkan oleh desain dari Bukalapak yang dinilai masih perlu banyak penyesuaian. Selain dari segi website, permasalahan lain yang dihadapi Bukalapak antara lain: keluhan pelanggan yang tidak ditanggapi dengan baik, retur pengembalian barang yang memiliki prosedur yang rumit, hingga masalah pembayaran.

\section{Landasan Teori dan Pengembangan Hipotesis}

Keputusan Pembelian adalah adalah tindakan untuk menyeleksi dua pilihan alternatif (Schiffman \& Kanuk, 2007). Saat melakukan pembelian, konsumen biasanya dihadapkan oleh banyak pilihan sehingga konsumen harus memilih produk dan jasa seperti apa yang harus dipilih yang disesuaikan dengan kebutuhannya. Menurut Kotler dan Armstrong (2004) keputusan pembelian adalah proses keputusan yang dialami konsumen secara aktual dalam memilih produk dan jasa. Adanya tindakan nyata bagi konsumen dalam memilih produk dan jasa yang akan dibeli. Katawetawaraks dan Wang (2011) menjelaskan bahwa belanja online adalah kegiatan pembelian produk (baik barang ataupun jasa) melalui media internet. Kegiatan belanja online meliputi kegiatan Business to Business (B2B) maupun Business to Consumers (B2C). Sementara pada penelitian kegiatan belanja online dikaitkan dengan B2C karena kegiatan pembelian yang dimaksudkan adalah kegiatan pembelian yang digunakan oleh konsumen sendiri, tidak dijual kembali.

Desain website merupakan salah bentuk komunikasi pemasaran. Desain website menjadi daya tarik sebagaimana iklan dalam penjualan offline (Widiyanto \& Prasilowati, 2015). Desain berarti merubah sebuah kondisi dimana objek yang akan dirubah menjadi lebih baik dari kondisi awalannya, dari sulit menjadi mudah dan begitu seterusnya. Desain memiliki tujuan yang dicapai. Tujuan itu berupa nilai, yang berarti nilai dari sebuah desain merupakan pencapaian terhadap tujuannya. Desain dikatakan mencapai tujuan jika, memenuhi kriteria fungsi, sesuai dengan karakteristik produk, memenuhi kriteria operasional, memenuhi nilai etik yang berlaku pada masyarakat dan tergantung pada objek yang didesain. Desain juga dirancang berdasarkan analisis data dan kajian pemikiran orang lain (Andri, 2010). Website yang efektif dapat dikatakan ketika pengguna dengan cepat dan efisien bisa mendapatkan informasi yang diinginkan tanpa menunda lama (Bordbar, 2016).

Reputasi vendor merupakan suatu citra yang melekat pada nama dari produk atau perusahaan yang memberi kesan kuat akan nama tersebut. Reputasi merupakan suatu identitas yang merupakan akumulasi nilai yang dilakukan oleh kelompok masyarakat ataupun konsumen. Herbig, Milewicz, \& Golden (1994) menyatakan bahwa reputasi cenderung mencerminkan kompetensi dan keunggulan produk atau perusahaan dibandingkan pesaingnya. Reputasi umumnya berkaitan dengan pengalaman pelanggan, pembicaraan orang maupun pemberitaan media atas produk atau perusahaan tersebut. Xu dan Yadav (2003), Li, Browne, dan Chau (2006) menyebutkan bahwa reputasi yang berdasarkan umpan balik dapat menguatkan sikap seseorang terhadap belanja online. Penjual yang memiliki track record, umpan balik yang positif dan testimonial yang baik diharapkan mampu menguatkan sikap konsumen untuk melakukan transaksi pembelian online.

Persepsi kemudahan transaksi didefinisikan sebagai sejauh mana seseorang percaya terhadap penggunaan teknologi informasi tersebut sehingga mudah untuk digunakan. Jika seseorang percaya terhadap teknologi yang digunakan maka dia akan menggunakannya sehingga persepsi kemudahan ini juga merupakan kepercayaan tentang proses pengambilan keputusan menurut (Jogiyanto, 2007). Menurut Widyastuti (2009) dalam Maulidiyah (2017) yang mendasar pada Tsu Wa (2002), mendefinisikan persepsi kemudahan sebagai suatu persepsi dimana seseorang tidak menemui adanya kesulitan dalam melakukan aktivitas. 


\section{Ikhsan Nurahman, Anggraeni Pratama Indrianto}

Dimana pernyataan menunjukkan bahwa bagi pemakai teknologi informasi akan merasa mudah jika mereka sudah percaya dengan adanya teknologi yang digunakan. Sehingga pengguna tersebut merasa bermanfaat bagi dirinya untuk menggunakan teknologi infromasi tersebut.

Berdasarkan berbagai fenomena dan permasalahan diatas, hipotesis yang diajukan dalam penelitian ini adalah:

$\boldsymbol{H}_{1}$ : Electronic Word of Mouth secara parsial berpengaruh signifikan terhadap Keputusan Pembelian Situs Online Bukalapak di Yogyakarta.

$\boldsymbol{H}_{2}$ : Kualitas Website secara parsial berpengaruh signifikan terhadap Keputusan Pembelian Situs Online Bukalapak di Yogyakarta.

$\boldsymbol{H}_{3}$ : Reputasi Vendor secara parsial berpengaruh signifikan terhadap Keputusan Pembelian Situs Online Bukalapak di Yogyakarta.

$\boldsymbol{H}_{4} \quad$ : Persepsi Kemudahan Transaksi secara parsial berpengaruh signifikan terhadap Keputusan Pembelian Situs Online Bukalapak di Yogyakarta.

Penelitian ini bertujuan untuk menguji dan menganalisis kelima hipotesis tersebut dan memiliki harapan agar penelitian ini dapat memberikan sumbangsih pemikiran pada Bukalapak untuk melakukan pengambilan keputusan manajemen di masa yang akan datang.

\section{Metode Penelitian}

Penelitian ini merupakan penelitian penjelasan (explanatory research). Penelitian ini dilakukan pada Januari 2021 dan berakhir pada Juli 2021 yang dilakukan di Yogyakarta. Penelitian ini menggunakan data primer dan data sekunder. Data primer dalam penelitian ini berupa jawaban dari kuesioner atas pertanyaan yang dibuat oleh peneliti. Skala pengukuran variabel dalam penelitian ini menggunakan skala Likert. Skala Likert digunakan untuk mengukur sikap, pendapat, dan persepsi seseorang atau sekelompok orang tentang fenomena sosial. Dalam penelitian, fenomena sosial ini telah ditetapkan secara spesifik oleh peneliti, yang selanjutnya disebut sebagai variabel penelitian (Sekaran, 2016). Dengan skala Likert, maka variabel yang akan diukur dijabarkan menjadi indikator variabel. Kemudian indikator tersebut dijadikan sebagai titik tolak untuk menyusun item-item instrumen yang dapat berupa pernyataan atau pertanyaan (Sekaran, 2016). Sedangkan data sekunder dalam penelitian ini adalah informai yang diperoleh melalui internet mengenai e-commerce Bukalapak. Populasi dalam penelitian ini adalah seseorang yang berada di Yogyakarta, berusia minimal dari 14 tahun, dan pernah melakukan pembelian pada e-commerce Bukalapak. Sampel yang diambil dalam penelitian ini berjumlah 120 responden dengan metode purposive sampling. Metode analisis yang digunakan dalam penelitian ini adalah metode regresi linier berganda.

\section{Hasil Penelitian}

Hasil penelitian yang akan dijabarkan dimulai dengan hasil uji validitas dan reliabilitas terhadap 30 responden, kemudian analisis deskriptif responden, hasil analisis regresi berganda, hasil uji hipotesis, dan hasil koefisien determinasi untuk 120 responden.

Uji Validitas. Tingkat validitas dapat diukur dengan cara membandingkan nilai $r$ hitung pada tabel kolom Corrected Item-Total Correlation dengan nilai $\mathrm{r}$ tabel dengan ketentuan untuk degree of freedom $(\mathrm{df})=\mathrm{n}-2$, dimana $\mathrm{n}$ adalah jumlah sampel yang digunakan dan $\mathrm{k}$ adalah jumlah variabel independennya (Ghozali, 2013). $\mathrm{r}$ tabel pada penelitian ini adalah:

Bila: $\quad r$ hitung $>r$ tabel, berarti pernyataan tersebut dinyatakan valid.

$r$ hitung $<r$ tabel, berarti pernyataan tersebut dinyatakan tidak valid. 
Nilai $\mathrm{r}$ tabel diperoleh dari tabel $\mathrm{r}$ product moment. Untuk uji validitas digunakan sampel sebanyak $\mathrm{n}=30$, pada tingkat signifikansi alpha $=5 \%$ besarnya nilai $\mathrm{r}$ tabel $=0.3610$ didapatkan hasil sebagai berikut:

Tabel 2. Rekapitulasi Hasil Uji Validitas

\begin{tabular}{|c|c|c|c|c|}
\hline Variabel & Indikator & $\underset{\text { hitung }}{\mathbf{r}}$ & $r$ tabel & Keterangan \\
\hline \multirow{3}{*}{$\begin{array}{l}\text { Electronic } \\
\text { Word of Mouth } \\
\qquad\left(\mathrm{X}_{1}\right)\end{array}$} & $\begin{array}{l}\text { Saya menemukan banyak komentar } \\
\text { mengenai online shop Bukalapak yang } \\
\text { ditulis oleh konsumen dalam sebuah } \\
\text { media sosial }\end{array}$ & 0.794 & 0.361 & Valid \\
\hline & $\begin{array}{l}\text { Saya dapat menemukan informasi dari } \\
\text { jejaring sosial berkaitan dengan produk } \\
\text { dan jasa dari online shop Bukalapak }\end{array}$ & 0.783 & 0.361 & Valid \\
\hline & $\begin{array}{l}\text { Saya menemukan banyak pendapat } \\
\text { positif mengenai online shop Bukalapak. }\end{array}$ & 0.794 & 0.361 & Valid \\
\hline \multirow{3}{*}{$\begin{array}{c}\text { Kualitas } \\
\text { Website }\left(\mathrm{X}_{2}\right)\end{array}$} & $\begin{array}{l}\text { Menurut saya, website Bukalapak mudah } \\
\text { untuk dipahami dan digunakan. }\end{array}$ & 0.823 & 0.361 & Valid \\
\hline & $\begin{array}{l}\text { Website Bukalapak mampu memberikan } \\
\text { informasi yg jelas mengenai produk dan } \\
\text { jasa yang sedang saya cari. }\end{array}$ & 0.798 & 0.361 & Valid \\
\hline & $\begin{array}{l}\text { Website Bukalapak memiliki interaksi } \\
\text { layanan yang baik dan fast response. }\end{array}$ & 0.626 & 0.361 & Valid \\
\hline \multirow{3}{*}{$\begin{array}{c}\text { Reputasi } \\
\text { Vendor }\left(\mathrm{X}_{3}\right)\end{array}$} & $\begin{array}{l}\text { Saya sering mendengar orang-orang } \\
\text { disekeliling saya membicarakan } \\
\text { kebaikan online shop Bukalapak. }\end{array}$ & 0.797 & 0.361 & Valid \\
\hline & $\begin{array}{l}\text { Bukalapak adalah website jual beli online } \\
\text { yang dikenal baik oleh masyarakat. }\end{array}$ & 0.904 & 0.361 & Valid \\
\hline & $\begin{array}{l}\text { Saya mengenal Bukalapak sebagai } \\
\text { website jual beli online yang memiliki } \\
\text { cirikhas tertentu. }\end{array}$ & 0.786 & 0.361 & Valid \\
\hline \multirow{6}{*}{$\begin{array}{c}\text { Persepsi } \\
\text { Kemudahan } \\
\text { Transaksi }\left(\mathrm{X}_{4}\right)\end{array}$} & $\begin{array}{l}\text { E-commerce Bukalapak merupakan } \\
\text { online shop yang bersahabat, karena } \\
\text { mudah dipelajari. }\end{array}$ & 0.661 & 0.361 & Valid \\
\hline & $\begin{array}{l}\text { Website Bukalapak mudah untuk } \\
\text { dikendalikan }\end{array}$ & 0.743 & 0.361 & Valid \\
\hline & $\begin{array}{l}\text { Website Bukalapak memiliki daya visual } \\
\text { yang jelas dan mudah untuk dimengerti. }\end{array}$ & 0.769 & 0.361 & Valid \\
\hline & $\begin{array}{l}\text { Website Bukalapak bersifat fleksibel dan } \\
\text { mudah disesuaikan dengan keinginan. }\end{array}$ & 0.706 & 0.361 & Valid \\
\hline & $\begin{array}{l}\text { Ketika sudah terbiasa membuka online } \\
\text { shop Bukalapak dan mudah dioperasikan, } \\
\text { membuat saya menjadi terampil. }\end{array}$ & 0.669 & 0.361 & Valid \\
\hline & $\begin{array}{l}\text { Website Bukalapak cenderung mudah } \\
\text { untuk digunakan. }\end{array}$ & 0.608 & 0.361 & Valid \\
\hline
\end{tabular}


Ikhsan Nurahman, Anggraeni Pratama Indrianto

\begin{tabular}{|c|c|c|c|c|}
\hline Variabel & Indikator & $\underset{\text { hitung }}{\mathbf{r}}$ & $r$ tabel & Keterangan \\
\hline \multirow{6}{*}{$\begin{array}{c}\text { Keputusan } \\
\text { Pembelian (Y) }\end{array}$} & $\begin{array}{l}\text { Saya selalu memilih produk di online } \\
\text { shop Bukalapak karena sesuai dengan } \\
\text { kebutuhan dan keinginan saya }\end{array}$ & 0.745 & 0.361 & Valid \\
\hline & $\begin{array}{l}\text { Saya selalu memilih merek Bukalapak } \\
\text { karena sesuai dengan kebutuhan dan } \\
\text { keinginan saya }\end{array}$ & 0.769 & 0.361 & Valid \\
\hline & $\begin{array}{l}\text { Online shop Bukalapak memberikan } \\
\text { banyak pilihan saluran distribusi, } \\
\text { sehingga saya dapat memilih yang paling } \\
\text { sesuai dengan saya. }\end{array}$ & 0.727 & 0.361 & Valid \\
\hline & $\begin{array}{l}\text { Saya cenderung melakukan pembelian } \\
\text { saat online shop Bukalapak mengadakan } \\
\text { promo/diskon tertentu. }\end{array}$ & 0.632 & 0.361 & Valid \\
\hline & $\begin{array}{l}\text { Apabila sedang diadakan promo/diskon } \\
\text { saya cenderung melakukan pembelian } \\
\text { dalam jumlah yang lebih banyak. maupun } \\
\text { non tunai. }\end{array}$ & 0.645 & 0.361 & Valid \\
\hline & $\begin{array}{l}\text { Banyaknya metode pembayaran yang } \\
\text { diterapkan oleh online shop Bukalapak, } \\
\text { mempermudah saya melakukan } \\
\text { pembelian (transfer bank, supermarket, } \\
\text { bayar ditempat, dan sebagainya). }\end{array}$ & 0.711 & 0.361 & Valid \\
\hline
\end{tabular}

Sumber: Data primer diolah, 2021

Uji Reliabilitas. Reliabilitas adalah apabila suatu alat pengukuran sudah dinyatakan valid, maka tahap berikutnya yaitu mengukur reliabilitas dari alat. Reliabilitas menunjuk pada kesamaan data dalam waktu yang berbeda. Instrumen yang reliabel adalah instrumen yang bila digunakan beberapa kali untuk mengukur obyek yang sama, akan menghasilkan data yang sama (Ghozali, 2013). Variabel dinyatakan reliabel jika alpha Cronbach > 0.6 (Ghozali, 2013). Berikut hasil uji reliabilitas dalam penelitian ini:

Tabel 3. Rekapitulasi Hasil Uji Reliabilitas

\begin{tabular}{|c|c|c|c|}
\hline Variabel & $\begin{array}{c}\text { Cronbach } \\
\text { Alpha }\end{array}$ & r tabel & Keterangan \\
\hline $\begin{array}{c}\text { Electronic Word of Mouth } \\
\left(\mathrm{X}_{1}\right)\end{array}$ & 0.697 & 0.60 & Reliabel \\
\hline Kualitas Website $\left(\mathrm{X}_{2}\right)$ & 0.601 & 0.60 & Reliabel \\
\hline Reputasi Vendor $\left(\mathrm{X}_{3}\right)$ & 0.773 & 0.60 & Reliabel \\
\hline $\begin{array}{c}\text { Persepsi Kemudahan } \\
\text { Transaksi }\left(\mathrm{X}_{4}\right)\end{array}$ & 0.784 & 0.60 & Reliabel \\
\hline Keputusan Pembelian $(\mathrm{Y})$ & 0.697 & 0.60 & Reliabel \\
\hline
\end{tabular}

Sumber: Data primer diolah, 2021

Analisis Deskriptif Karateristik Responden. Analisis ini digunakan untuk memberikan gambaran mengenai responden penelitian, apakah dengan karakteristik responden 
yang berbeda-beda mempunyai penilaian yang sama ataukah tidak. Dalam penelitian ini yang dijadikan sebagai karakteristik responden adalah jenis kelamin responden, usia responden, status/pekerjaan, dan tingkat pendapatan (perbulan). Berdasarkan analisis deskriptif dari 120 responden, didapatkan hasil sebagai berikut:

Tabel 4. Jenis Kelamin Responden

\begin{tabular}{|c|c|c|}
\hline Jenis Kelamin & Frekuensi & Presentase \\
\hline Laki-laki & 46 & $38.3 \%$ \\
\hline Perempuan & 74 & $61.7 \%$ \\
\hline
\end{tabular}

Sumber: Data primer diolah, 2021

Berdasarkan pada Tabel 4. maka dapat disimpulkan bahwa hampir sebagian besar berjenis kelamin perempuan sebanyak 74 responden atau $61,7 \%$. Sedangkan sisanya sebanyak 46 responden berjenis kelamin laki-laki dengan persentase sebesar 38,3\%.

Tabel 5. Usia Responden

\begin{tabular}{|c|c|c|}
\hline Usia & Frekuensi & Presentase \\
\hline $11-20$ tahun & 31 & $25.8 \%$ \\
\hline $21-30$ tahun & 73 & $60.8 \%$ \\
\hline $31-40$ tahun & 12 & $10.0 \%$ \\
\hline $41-50$ tahun & 2 & $1.7 \%$ \\
\hline $\begin{array}{c}\text { Lebih dari } 50 \\
\text { tahun }\end{array}$ & 2 & $1.7 \%$ \\
\hline
\end{tabular}

Sumber: Data primer diolah, 2021

Berdasarkan pada Tabel 5. maka dapat disimpulkan bahwa hampir sebagian besar responden berusia antara 21 - 30 tahun sebanyak 73 responden atau $60,8 \%$. Terdapat 31 responden berusia antara $11-20$ tahun dengan persentase sebesar $25,8 \%$. Selanjutnya terdapat 12 responden yang berusia antara $31-40$ tahun dengan persentase sebesar $10 \%$. Sedangkan sisanya sebanyak 2 responden berusia antara 41- 50 tahun dan lebih dari 50 tahun dengan persentase sebesar 1,7\%.

Tabel 6. Status Pekerjaan Responden

\begin{tabular}{|c|c|c|}
\hline Status/Pekerjaan & Frekuensi & Presentase \\
\hline Pelajar & 10 & $8.3 \%$ \\
\hline Mahasiswa & 69 & $57.5 \%$ \\
\hline $\begin{array}{c}\text { Pegawai Negeri Sipil } \\
\text { (PNS) }\end{array}$ & 9 & $7.5 \%$ \\
\hline Karyawan Swasta & 18 & $15.0 \%$ \\
\hline Wirausaha & 11 & $9.2 \%$ \\
\hline Lainnya & 3 & $2.5 \%$ \\
\hline
\end{tabular}

Sumber: Data primer diolah, 2021

Berdasarkan pada Tabel 6. maka dapat disimpulkan bahwa lebih dari setengah dari jumlah sampel responden mempunyai pekerjaan sebagai mahasiswa sebanyak 69 responden atau $57,5 \%$. Terdapat 18 responden atau $15 \%$ yang mempunyai pekerjaan sebagai karyawan swasta. 
11 responden atau 9,2\% mempunyai pekerjaan sebagai wirausaha. Sedangkan terdapat 10 responden atau $8,3 \%$ mempunyai pekerjaan sebagai pelajar. Dan sisanya sebanyak 3 responden atau $2,5 \%$ mempunyai pekerjaan lain-lain.

Tabel 7. Pendapatan Perbulan Responden

\begin{tabular}{|c|c|c|}
\hline Pendapatan & Frekuensi & Presentase \\
\hline $\mathrm{Rp} \mathrm{500.000-Rp} \mathrm{1.000.000}$ & 6 & $5.0 \%$ \\
\hline > Rp 1.000.000 - Rp & 35 & $29.2 \%$ \\
2.000 .000 & & \\
\hline > Rp 2.000.000 - Rp \\
3.000 .000 & 41 & $34.2 \%$ \\
\hline > Rp 3.000.000 & 38 & $31.7 \%$ \\
\hline
\end{tabular}

Sumber: Data primer diolah, 2021

Berdasarkan pada Tabel 7. maka dapat disimpulkan bahwa jumlah pendapatan tertinggi antara $>\mathrm{Rp} 2.000 .000$ - Rp 3.000.000 sebanyak 41 responden atau 34,2\%. Terdapat 38 responden atau $31,7 \%$ mempunyai pendapatan $>\mathrm{Rp} 3.000 .000$. Sedangkan sebanyak 35 responden atau $29,2 \%$ mempunyai pendapatan antara $>$ Rp 1.000.000 - Rp 2.000.000. Dan sisanya sebanyak 6 responden atau 5\% mempunyai pendapatan antara Rp 500.000 - Rp 1.000.000.

Analisis Regresi Liniear Berganda. Hasil pengujian terhadap model regresi berganda terhadap faktor-faktor yang mempengaruhi keputusan pembelian online pada Bukalapak, dapat dilihat dalam Tabel 8 berikut:

Tabel 8. Hasil Perhitungan Regresi Linier Berganda

\begin{tabular}{|c|c|c|c|c|c|c|}
\hline \multirow{2}{*}{ MODEL } & \multicolumn{2}{|c|}{$\begin{array}{l}\text { Unstandarized } \\
\text { Coefficients }\end{array}$} & \multirow{2}{*}{$\begin{array}{c}\begin{array}{c}\text { Standarized } \\
\text { Coefficients }\end{array} \\
\text { Beta }\end{array}$} & \multirow[t]{2}{*}{$\mathbf{t}$} & \multirow[t]{2}{*}{ Sig. } & \multirow[t]{2}{*}{ Ket } \\
\hline & B & $\begin{array}{l}\text { Std. } \\
\text { Error }\end{array}$ & & & & \\
\hline (Constant) & 5.711 & 1.547 & & 3.692 & .000 & \\
\hline $\begin{array}{c}\text { Electronic Word of } \\
\text { Mouth }\end{array}$ & .453 & .111 & .278 & 4.088 & .000 & Sig \\
\hline Kualitas Website & .289 & .112 & .167 & 2.576 & .011 & Sig \\
\hline Reputasi Vendor & .594 & .105 & .406 & 5.686 & .000 & Sig \\
\hline $\begin{array}{c}\text { Persepsi } \\
\text { Kemudahan } \\
\text { Transaksi }\end{array}$ & .181 & .064 & .189 & 2.810 & .006 & Sig \\
\hline \multicolumn{7}{|c|}{ Dependent Variable : Keputusan Pembelian } \\
\hline$R$ Square & $: 0.628$ & & & & & \\
\hline Sign $F$ & $: 48.59$ & & & & & \\
\hline Sig. & 0.000 & & & & & \\
\hline
\end{tabular}

Sumber: Data primer diolah, 2021

Berdasarkan hasil analisis regresi linier berganda pada tabel 4.8 diperoleh persamaan regresi sebagai berikut:

$$
Y=5.711+0.453 X 1+0.289 X 2+0.594 X 3+0.181 X 4
$$




\section{Ikhsan Nurahman, Anggraeni Pratama Indrianto}

Berdasarkan berbagai parameter dalam regresi mengenai faktor-faktor yang mempengaruhi keputusan pembelian online, maka dapat diberikan intepretasi sebagai berikut: 1. Nilai konstanta 5.711 (positif) yang berarti bahwa jika variabel bebas yaitu electronic word of mouth (X1), kualitas website (x2), reputasi vendor (x3), dan persepsi kemudahan transaksi (x4) tidak berubah atau konstan, maka keputusan pembelian (y) akan konstan.

2. Koefisien regresi electronic word of mouth diperoleh sebesar 0.453 dengan arah positif menyatakan bahwa jika variabel bebas lainnya bernilai konstan, maka besarnya pengaruh dari variabel electronic word of mouth terhadap keputusan pembelian (dependen) adalah sebesar 0.453 , artinya apabila electronic word of mouth naik $1 \%$ maka keputusan pembelian akan baik sebesar $4.53 \%$ dan sebaliknya apabila electronic word of mouth turun $1 \%$ maka keputusan pembelian akan turun sebesar $4.53 \%$.

3. Koefisien regresi kualitas website diperoleh sebesar 0.289 dengan arah positif menyatakan bahwa jika variabel bebas lainnya bernilai konstan, maka besarnya pengaruh dari variabel kualitas website terhadap keputusan pembelian (dependen) adalah sebesar 0.289, artinya apabila kualitas website naik $1 \%$ maka keputusan pembelian akan baik sebesar $2.89 \%$ dan sebaliknya apabila kualitas website turun $1 \%$ maka keputusan pembelian akan turun sebesar $2.89 \%$.

4. Koefisien regresi reputasi vendor diperoleh sebesar 0.594 dengan arah positif menyatakan bahwa jika variabel bebas lainnya bernilai konstan, maka besarnya pengaruh dari variabel reputasi vendor terhadap keputusan pembelian (dependen) adalah sebesar 0.594, artinya apabila reputasi vendor naik 1\% maka keputusan pembelian akan baik sebesar 5.94\% dan sebaliknya apabila reputasi vendor turun $1 \%$ maka keputusan pembelian akan turun sebesar $5.94 \%$.

5. Koefisien regresi persepsi kemudahan transaksi diperoleh sebesar 0.181 dengan arah positif menyatakan bahwa jika variabel bebas lainnya bernilai konstan, maka besarnya pengaruh dari variabel persepsi kemudahan transaksi terhadap keputusan pembelian (dependen) adalah sebesar 0.181 , artinya apabila persepsi kemudahan transaksi naik $1 \%$ maka keputusan pembelian akan baik sebesar $1.81 \%$ dan sebaliknya apabila persepsi kemudahan transaksi turun $1 \%$ maka keputusan pembelian akan turun sebesar $1.81 \%$.

Uji t (parsial). Uji koefisien regresi secara parsial digunakan untuk mengetahui arah dan pengaruh dari masing-masing variabel bebas terhadap variabel terikat secara parsial (Ghozali, 2013). Dari Tabel 8 dapat dilihat bahwa nilai t hitung sebesar 4.088 dan nilai signifikansi sebesar 0.000 yang nilainya dibawah 0.05 dengan demikian nilai signifikansi yang lebih kecil $(\mathrm{a}=0.05)$, maka $\mathrm{H} 1$ diterima artinya variabel electronic word of mouth $(\mathrm{X} 1)$ secara parsial berpengaruh positif signifikan terhadap keputusan pembelian. Kemudian, nilai t hitung sebesar 2.576 dan nilai signifikansi sebesar 0.011 yang nilainya dibawah 0.05 dengan demikian nilai signifikansi yang lebih kecil $(\mathrm{a}=0.05)$, maka $\mathrm{H} 2$ diterima artinya variabel kualitas website (X2) secara parsial berpengaruh positif signifikan terhadap keputusan pembelian. Lalu untuk nilai t hitung sebesar 5.686 dan nilai signifikansi sebesar 0.000 yang nilainya dibawah 0.05 dengan demikian nilai signifikansi yang lebih kecil $(\mathrm{a}=0.05)$, maka H3 diterima artinya variabel reputasi vendor (X3) secara parsial berpengaruh positif signifikan terhadap keputusan pembelian. Dan terakhir nilai t hitung sebesar 2.810 dan nilai signifikansi sebesar 0.006 yang nilainya dibawah 0.05 dengan demikian nilai signifikansi yang lebih kecil $(\mathrm{a}=0.05)$, maka $\mathrm{H} 4$ diterima artinya variabel persepsi kemudahan transaksi (X3) secara parsial berpengaruh positif signifikan terhadap keputusan pembelian.

Uji Koefisien Determinasi. Koefisien Determinasi $\left(\mathrm{R}^{2}\right)$ digunakan untuk mengukur seberapa jauh kemampuan model dalam menerangkan variabel dependen (Ghozali, 2013). Berdasarkan Tabel 8 diatas, dapat dilihat bahwa nilai koefisien determinasi adalah sebesar 0.628 artinya $62.8 \%$ variasi dari keputusan pembelian dapat dijelaskan oleh keempat variabel 


\section{Ikhsan Nurahman, Anggraeni Pratama Indrianto}

independen yang terdiri dari electronic word of mouth, kualitas website, reputasi vendor, dan persepsi kemudahan transaksi. Sedangkan 37.2\% sisanya dijelaskan oleh sebab-sebab lain atau dipengaruhi variabel lain diluar variabel bebas yang diteliti.

\section{Pembahasan}

Pengaruh electronic word of mouth, kualitas website, reputasi vendor, dan persepsi kemudahan tansaksi terhadap keputusan pembelian. Berdasarkan hasil uji regresi, keempat variabel independen yang terdiri dari electronic word of mouth, kualitas website, reputasi vendor, dan persepsi kemudahan tansaksi secara bersama-sama berpengaruh positif dan signifikan terhadap keputusan pembelian e-commerce Bukalapak di Yogyakarta. Hal ini dapat dilihat dari hasil koefisien determinasi berganda ( $R$ Square) sebesar 0.628 (62.8\%) dan signifikansi sebesar 0.000 (kurang dari 0.05 berarti memiliki pengaruh yang signifikan). Nilai $R$ Square yang menunjukkan 0.628 menandakan bahwasanya keputusan pembelian $e$ commerce Bukalapak tidak hanya dipengaruhi oleh variabel electronic word of mouth, kualitas website, reputasi vendor, dan persepsi kemudahan saja. Namun 37.2\% sisanya dipengaruhi oleh variabel lain yang tidak diteliti dalam penelitian ini. Penelitian ini mendukung penelitian sebelumnya yang dilakukan oleh Nainggolan (2017) yang berjudul "Keputusan Konsumen Membeli Melalui Online" menunjukkan bahwa variabel kemenarikan desain website, reputasi vendor, dan persepsi kemudahan transaksi berpengaruh signifikan terhadap keputusan pembelian.

Pengaruh electronic word of mouth terhadap keputusan pembelian. Berdasarkan hasil uji regresi, variabel Electronic Word of Mouth terbukti berpengaruh positif dan signifikan terhadap Keputusan Pembelian E-Commerce Bukalapak di Yogyakarta dengan nilai signifikansi 0.000. Hal ini berarti faktor Electronic Word of Mouth yang diukur menggunakan penemuan mengenai banyaknya komentar di berbagai sosial media mengenai Bukalapak, penemuan informasi dari sosial media mengenai Bukalapak, dan penemuan banyaknya pendapat positif masyarakat mengenai Bukalapak merupakan salah satu faktor yang mempengaruhi keputusan pembelian Bukalapak pada masyarakat di Yogyakarta. Electronic Word of Mouth adalah saran komunikasi yang berupa saran negatif maupun positif yang terjadi di internet Hennig-Thurau, Gwinner, Walsh, \& Gremler (2004). Setiap konsumen yang sudah mengkonsumsi suatu produk akan memberikan penilaian sendiri untuk produk tersebut, dan tidak bisa dipengaruhi karena berasal dari diri sendiri, setelah itu jika konsumen tersebut puas maupun tidak puas atas konsumsi produk tersebut maka konsumen tersebut akan menceritakan review produk tersebut ke orang lain yang mempunyai account di social media, e-mail, blog, maupun website yang sebelumnya sudah dibuat. Internet telah menyebabkan informasi dari mulut ke mulut secara simultan di mana-mana dan menjadi keharusan secara fisik dan hadir di mana saja Xia \& Bechwati (2008). Penelitian ini mendukung penelitian sebelumnya milik Sari, Saputra, \& Husein (2017) yang menyatakan bahwa electronic word of mouth berpengaruh terhadap keputusan pembelian pada Bukalapak.com

Pengaruh kualitas website terhadap keputusan pembelian. Berdasarkan hasil uji regresi, variabel Kualitas Website terbukti berpengaruh positif dan signifikan terhadap Keputusan Pembelian E-Commerce Bukalapak di Yogyakarta dengan nilai signifikansi 0.011. Hal ini berarti faktor Kualitas Website yang diukur menggunakan mudahnya memahami dan menggunakan situs Bukalapak, kemampuan Bukalapak memberikan informasi yang dibutuhkan konsumen, dan kecepatan interaki antara Bukalapak dan konsumen merupakan salah satu faktor yang mempengaruhi keputusan pembelian Bukalapak pada masyarakat di Yogyakarta. Kualitas website adalah hal yang sangat perlu diperhatikan oleh semua yang 


\section{Ikhsan Nurahman, Anggraeni Pratama Indrianto}

melakukan proses penjualan secara online. Tidak hanya dilihat dari kemasannya yang menarik, tetapi bagaimana membuat konsumen berpikir bahwa apa yang mereka butuhkan dapat mereka temukan dalam website tersebut, sehingga pelanggan akan merasa puas. Kualitas website merupakan faktor yang sangat penting dalam penjualan secara online dan memiliki nilai tersendiri bagi konsumen. Bavarsad, Rahimi, \& Mennatyan (2013) menjelaskan bahwa website yang baik memiliki kualitas operasional yang memungkinkan pembeli untuk melakukan aktivitas $e$-shopping mereka dengan mudah dan efisiensi. Beberapa dimensi kualitas website telah dipastikan dan disebutkan dalam berbagai penelitian. Parasuraman, Zeithaml, \& Berry (1998) mengidentifikasi ada lima dimensi kualitas pelayanan yakni reliability, responsiveness, jaminan, empati, dan bukti fisik. Namun, secara umum, yang disoroti dalam kualitas website adalah kualitas pelayanannya. Penelitian ini mendukung penelitian sebelumnya milik Irshadi \& Hendayani (2016) yang menyatakan bahwa kualitas website MatahariMall.com berpengaruh terhadap keputusan pembelian.

Pengaruh reputasi vendor terhadap keputusan pembelian. Berdasarkan hasil uji regresi, variabel reputasi vendor terbukti berpengaruh positif dan signifikan terhadap keputusan pembelian e-commerce Bukalapak di Yogyakarta dengan nilai signifikansi 0.000. Hal ini berarti faktor reputasi vendor yang diukur menggunakan kebaikan online shop yang ada di e-commerce Bukalapak, persepsi baik yang dimiliki Bukalapak, dan cirikhas dari Bukalapak merupakan salah satu faktor yang mempengaruhi keputusan pembelian Bukalapak pada masyarakat di Yogyakarta. Reputasi merupakan suatu atribut yang diberikan kepada penjual berdasarkan pada informasi dari orang atau sumber lain. Reputasi dapat menjadi penting untuk membangun kepercayaan seorang konsumen terhadap penjual karena konsumen tidak memiliki pengalaman pribadi dengan penjual, Reputasi dari mulut ke mulut yang juga dapat menjadi kunci ketertarikan konsumen. Informasi positif yang didengar oleh konsumen tentang penjual dapat mengurangi persepsi terhadap resiko dan ketidakamanan ketika bertransaksi dengan penjual. Hal ini dapat membantu meningkatkan kepercayaan konsumen tentang kompetensi, benevolence, dan integritas pada penjual. Herbig, Milewicz, \& Golden (1994) menyatakan bahwa reputasi cenderung mencerminkan kompetensi dan keunggulan produk atau perusahaan dibanding-kan pesaingnya. Reputasi umumnya berkaitan dengan pengalaman pelanggan, pembicaraan orang maupun pemberitaan media atas produk atau perusahaan tersebut. Penelitian ini mendukung penelitian sebelumnya milik Nainggolan (2017) yang menyatakan bahwa reputasi vendor berpengaruh terhadap keputusan pembelian.

Pengaruh persepsi kemudahan tansaksi terhadap keputusan pembelian. Berdasarkan hasil uji regresi, variabel persepsi kemudahan tranasaksi terbukti berpengaruh positif dan signifikan terhadap Keputusan Pembelian E-Commerce Bukalapak di Yogyakarta dengan nilai signifikansi 0.006. Hal ini berarti faktor persepsi kemudahan transaksi yang diukur menggunakan mudahnya mempelajari e-commerce Bukalapak, mudahnya mengendalikan $e$ commerce Bukalapak, Bukalapak memiliki daya visual yang baik, Bukalapak bersifat fleksibel, kemudahan Bukalapak membuat konsumen menjadi terampil menggunakan website tersebut, dan e-commerce Bukalapak mudah digunakan. Menurut Kotler, Armstrong, \& Keller (2007), mendefinisikan persepsi kemudahan sebagai suatu persepsi dimana seseorang tidak menemui adanya kesulitan dalam melakukan aktivitas. Dimana pernyataan menunjukkan bahwa bagi pemakai teknologi informasi akan merasa mudah jika mereka sudah percaya dengan adanya teknologi yang digunakan. Sehingga pengguna tersebut merasa bermanfaat bagi dirinya untuk menggunakan teknologi infromasi tersebut. Penelitian ini mendukung penelitian sebelumnya milik Nainggolan (2017) yang menyatakan bahwa kemudahan transaksi berpengaruh terhadap keputusan pembelian. 


\section{Kesimpulan}

Berdasarkan hasil analisis data diatas, maka dapat disimpulkan bahwa keempat variabel independen yang terdiri dari: electronic word of mouth, kualitas website, reputasi vendor, dan persepsi kemudahan transaksi baik berpengaruh positif dan signifikan terhadap keputusan pembelian e-commerce Bukalapak di Yogyakarta. Penelitian ini juga turut memberikan implikasi bagi Bukalapak dengan hasil yang diberikan dapat dilihat bahwasanya nilai pengaruh variabel persepsi kemudahan transaksi terhadap keputusan pembelian memiliki nilai yang paling kecil, oleh karena itu peneliti menyarankan agar Bukalapak lebih memperbanyak varian pembayaran sehingga dapat meningkatkan keputusan pembelian. Salah satu hal yang bisa dilakukan oleh Bukalapak adalah bekerjasama dengan perusahaan keuangan digital seperti OVO, Dana, dan Gopay.

\section{Daftar Pustaka}

Andri, M. (2010). Strategi Visual. Yogyakarta: Jalasutra.

Bavarsad, B., Rahimi, F., \& Mennatyan, M. A. (2013). A Study of the Effects of Website's Perceived Features on the Intention to Use E-shopping. World Applied Programming, $3(6), 252-263$.

Bordbar, F. (2016). The Effectiveness of Website Design in Higher Education Recruitment. Southern Utah University.

Gunasekaran, A., Patel, C., \& McGaughey, R. E. (2004). A Framework for Supply Chain Performance Measurement. International Journal of Production Economics, 87(3), 333347.

Ghozali, I. (2013). Aplikasi Analisis Multivariate dengan Program SPSS (2 ed.). Semarang: Badan Penerbit Universitas Diponegoro.

Hennig-Thurau, T., Gwinner, K. P., Walsh, G., \& Gremler, D. D. (2004). Electronic word-ofmouth via consumer-opinion platforms: What motivates consumers to articulate themselves on the Internet? Journal of Interactive Marketing, 18(1), 38-52. https://doi.org/https://doi.org/10.1002/dir.10073

Herbig, P., Milewicz, J., \& Golden, J. (1994). A Model of Reputation Building and Destruction. Journal of Business Research, 31.

Hidayat, W. (2014). Pengguna Internet Nomor Enam Dunia. Diambil dari Kominfo website: https://kominfo.go.id/content/detail/4286/pengguna-internet-indonesia-nomor-enam dunia/0/sorotan_media

Idea. (2019). E-Commerce yang Paling Banyak di Kunjungi di Indonesia. Diambil dari idea.or.id website: https://www.idea.or.id/infografis

Irshadi, F., \& Hendayani, R. (2016). Pengaruh Kualitas Website terhadap Keputusan Pembelian pada Pengunjung Website Mataharimall.com. Proceeding of Management, $3(3)$.

Jogiyanto. (2007). Sistem Informasi Keperilakuan (Revisi). Yogyakarta: Andi Offset.

Katawetawaraks, C., \& Wang, C. L. (2011). Online Shopper Behavior: Influences of Online Shopping Decision. Asian Journal of Business Research, 1(2), 66-74. https://doi.org/10.14707/ajbr.110012

Kotler, Philip, Armstrong, G., \& Keller, K. L. (2007). Manajemen Pemasaran (12 ed.). Klaten: PT Macanan Jaya.

Kotler, Phillip, \& Armstrong, G. (2004). Manajemen Pemasaran. Jakarta: Erlangga. 
Li, D., Browne, G. J., \& Chau, P. Y. K. (2006). An Empirical Investigation of Web Site Use Using a Commitment-Based Model. Decision Sciences, 37(3), 427-444. https://doi.org/https://doi.org/10.1111/j.1540-5414.2006.00133.x

Maulidiyah, S. (2017). Pengaruh Persepsi Manfaat, Kemudahan Penggunaan, dan Kesesuaian terhadap Keputusan Menggunakan Mobile Banking Bank Mandiri di Surabaya. Sekolah Tinggi Ilmu Ekonomi Perbanas.

Nainggolan, H. (2017). Keputusan Konsumen Membeli Melalui Online. Jurnal Ekonomi dan Bisnis. Jurnal Ekonomi dan Bisnis, 11(3), 201-214.

Parasuraman, A., Zeithaml, V. A., \& Berry, L. L. (1998). SERVQUAL: A Multiple Item Scale For Measuring Consumer Perception Of Service Quality. Journal of Retailing, 64(1), 12 37.

Sari, N., Saputra, M., \& Husein, J. (2017). Pengaruh Electronic Word of Mouth Terhadap Keputusan Pembelian Pada Toko Online Bukalapak.Com. Jurnal Manajemen Magister, 03(01), 96-106.

Schiffman, L. ., \& Kanuk, L. L. (2007). Perilaku Konsumen. Jakarta: Indeks Gramedia.

Turban, E., King, D., Lee, J., \& Viehland, D. (2004). Electronic Commerce : A Managerial Perspective. New Jersey: Prentice Hall.

Widiyanto, I., \& Prasilowati, S. L. (2015). Perilaku Pembelian melalui Internet. Jurnal Manajemen dan Kewirausahaan, 17(2).

Xia, L., \& Bechwati, N. N. (2008). Word of Mouth: The Role of Cognitive Personalization in Online Consumer Reviews. Journal of Interactive Advertising, 9(1), 108-128.

Xu, B., \& Yadav, S. (2003). Effect of Online Reputetion Services in Electronic Markets: A trust Based Empirical Study. Ninth Americas Conference on Information Systems. Texas: Texas Tech University. 